\title{
Bridging the Divide: Marriage Politics across THE CAUCASUS
}

\author{
Lara Fabian
}

Albert-Ludwigs-Universität, Freiburg

\begin{abstract}
The early relationships between the polities of Armenia and K'art'li in the South Caucasus and their neighbours in the North Caucasus is a central, but underappreciated, factor in the development of the South Caucasus' social and political world in the Hellenistic period. Typically, only military aspects of these interactions are considered (e.g., Alan raids and control thereof). Hazy evidence of cross-Caucasus marriage alliances preserved in both the Armenian and Georgian historiographic traditions, however, hints at a far wider sphere of interaction, despite the inherent challenges in gleaning historical reality from these medieval accounts. This paper contextualizes two stories of cross-Caucasus marriage related to foundational dynastic figures in the Armenian and Georgian traditions, Artašēs and P'arnavaz respectively, within a wider body of evidence for and thought about North-South Caucasus interaction. Taken as a whole, this consideration argues that North-South relationships should be seen as integral to the political development of the South Caucasus.
\end{abstract}

Keywords: Armenia, K`art`li, North Caucasus, Alans.

\section{Kings from the South, Queens from the North}

As the story goes, the first king of Armenia's Artašēsid dynasty, Artašēs I (r. ca. 188160 BCE), wed an Alan princess from the North Caucasus, Sat'enik. ${ }^{1}$ According to the account of this marriage preserved in Movsēs Xorenac'i's (MX) History of the Armenians (Patmut'iwn Hayoc'), the two met during an Alan incursion across the Kura River, after the Alans had overwhelmed the K'art'velians on their way south. In the course of a successful attempt to repel the Alans, Artašēs' army captured an Alan prince, the brother of Sat'enik. The princess came to Artašēs' attention while negotiating for

1 Movsēs Xorenac'i 2.50 . On the chronological confusion and projection of this passage into the 2nd century CE, see Toumanoff 1963, 283-284. 
her brother's release. Enthralled by her beauty, the king offered a treaty to her father, to exchange the prince for the princess. Sat'enik's father rebuffed this offer, leaving Artašēs to abduct the princess - a feat he accomplished by lassoing her across the Kura. He subsequently paid a hefty bride-price to the Alan king and was wed to the princess in a lavish ceremony, and they went on to have six sons.

There is another account of a North-South Caucasus marriage in the Lives of Georgia $\left(\left[K^{\prime}\right.\right.$ 'art'tlis Cxovreba $\left.]=K C\right)$. This story has the first king of the $\mathrm{P}^{\prime}$ arnavazad

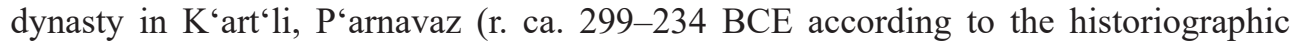
tradition), ${ }^{2}$ marrying a woman from region of Durżuket'i (mod. Ingushetia/Chechnya), ${ }^{3}$ and also marrying his sister to the king of the Alans. ${ }^{4}$ Although the $\mathrm{KC}$ is not specific about how $\mathrm{P}^{\prime}$ arnavaz and his bride met nor whether the woman was from a ruling family, the Georgian testimony is direct about the benefits of both marriage alliances for P'arnavaz' son, Saurmag, who succeeded his father. When Saurmag faced problems with other elite K'art'velian families, he was able to withdraw to his mother's people in the north, and with the help of them and of Alan kinsmen through his aunt, he defended his claim to the throne. ${ }^{5}$

It is impossible, of course, to use the medieval accounts preserved in MX and the $\mathrm{KC}$ as straightforward historical testimony. ${ }^{6}$ Composed far after the events described within and subject to significant layers of editing and rewriting in subsequent periods, they offer only shadowy hints at historical events. Nevertheless, they provide important clues about how local medieval societies understood their own pasts, and contain kernels of history that survived their complex transmission chains.

The narratives in both the Georgian and Armenian traditions place unions between North and South Caucasians as an important component of local rule. In the case of P'arnavaz, these alliances secured his son's succession. The fact that cross-Caucasus elite relationships were commonplace in $\mathrm{K}^{\prime}$ art'li has been long acknowledged by Georgian scholars. ${ }^{7}$ However, alliances with North Caucasian groups-both those explicitly discussed as Alans and others - have rarely been treated as a serious political phenomenon, or discussed in terms of the development of local authority and autonomy in the South Caucasus. ${ }^{8}$ Instead, we have treated the Greater Caucasus as if it were a barrier separating two distinct and separate spheres: one of the nomads in the north; another of emergent polities in the south. In fact, the borders between the spaces and the divisions between the communities were never so clear. The process of local state

2 Following the regnal dates of K'art'velian dynasts using the dates proposed in Toumanoff 1969; see also Rapp 2009, 652, note 18. Some argue for a later date for the consolidation of Hellenistic K'art'li, e.g., Meißner 2000, 188; Schottky 2012, 245-246; cf. Gagoshidze - Löhr - Ludwig 2008, 3.

$3 K C$, ed. S. Qauxč išvili 1955, 25-27. She is not explicitly named as being from a dynastic family, but she is said to be a descendent the eponymous hero, Kavkas: $K C$, ed. S. Qauxč išvili 1955, 25, l. 6.

$4 K C$, ed. S. Qauxč išvili 1955, 24, ll. 2-3.

5 KC, ed. S. Qauxč išvili 1955, 26, ll. 19-23; Thomson 1996, 38-39.

6 For example, in the case of Georgia, see the recent comments in Rapp 2014, 1-30 and the brief discussion in Schottky 2012, 242; Traina 2019, 23-24.

7 E.g., Melikišvili 1959, 355-356.

8 However, Braund 1994, 208-221; Wheeler 1977, 80-87. Versions of the idea of the South Caucasus as a space of steppe-sedentary mediation have been discussed, e.g., Gregoratti 2013, though often with a decided interested in who controlled specific mountain passes, on which, below. 


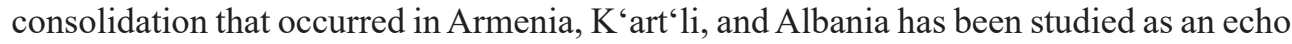
of the rise of the Hellenistic successor states in Mesopotamia and Anatolia, while the northern communities were relegated to the role of warlike northerners and threatening predators. $^{9}$

This viewpoint has a long history, rooted in the exclusion of steppe and steppeadjacent people more broadly from the historical narratives of sedentary societies. The earliest mentions of the steppe peoples are nothing more than descriptions of their military engagements with Neo-Assyrian and Urartian kings, ${ }^{10}$ and raids remain a frequent theme all the way through classical literature. ${ }^{11}$ Herodotus' paradigmatic ethnography of the Scythians cast them as a nomadic other par excellence, ${ }^{12}$ a sentiment that set the tone for subsequent Mediterranean treatments. By the time of Josephus, the civilization-ending peoples Gog and Magog were said to be Scythian nomads. ${ }^{13}$ Within the Alexander Romance tradition as well as in Syriac Christian thought, Gog and Magog were placed specifically in the North Caucasus, reinforcing the perception that the Greater Caucasus mountains marked the border of civilization. ${ }^{14}$ Despite being composed nearby, the accounts of the Alans and their kinsmen preserved by MX and in the $\mathrm{KC}$ are part of the tradition of etic descriptions of the steppe peoples, and rely on some of the same tropes about the warlike north that pervade accounts composed in more distant centres, although the full picture in these sources is more complicated. ${ }^{15}$ All of this has predisposed us to interpret sedentary-nomadic interaction, and therefore NorthSouth Caucasus interaction, as antagonistic rather than cooperative.

There is, however, another factor that has shaped our understanding of North-South Caucasus interaction: the historical understanding amongst scholars within the Russian Empire (who conducted much of the earliest research in this space) of the relationship between the ancient steppe societies that dominated the North Caucasus, and their own history. Already in Nikolai Karamzin's paradigmatic Istorija gosudarstva Rossijskogo (1818-1824), the idea had emerged that the Slavic ancestors of modern Russians could be traced back through earlier populations in the steppe, namely the Sarmatians and the Scythians. ${ }^{16}$ Although this perspective was never universally accepted in either popular or scholarly circles, debate about the nature of relationships between modern Russia and the ancient steppe nomads remained active through the 19 th and early 20 th centuries. ${ }^{17}$

9 E.g., the characterization of Sarmatians in Gagoshidze - Löhr - Ludwig 2008, 18-20.

10 Several Assyrian letters, for example, document a Cimmerian victory over the Urartians in the late 8th century BCE, the chronology of which is much debated, Roaf 2012, 211-213.

11 E.g., Diod. 2.43.4-6; Just. 1.1.6; 2.5.1-7; 2.3.8-18; Curt. Ruf. 7.8.18.

12 Hdt. 1.103-106, 130; 4.1-12; 4.78-80. Shaw 1982 on the quintessential alterity of the steppe nomads in Greek and Roman thought.

13 Josephus, Ant. Iud. 1.123.

14 Djurslev 2018; Van Bladel 2007.

15 Although the idea of 'the north' in the medieval historiography of the South Caucasus is rather more complex, see Rapp 2014, 125-140.

16 Karamzin 1818, I: 9-20. The idea was not Karamzin's alone, but was also present in the thoughts of Lomonsov and other post-Petrine intellectuals. This Russian version was not the only claim on steppe inheritance, with associations to Eastern European, and especially Polish, aristocracy developing already in the medieval period and holding continued relevance: Chrzanowski 1988; Sulimirski 1964.

17 This is a discourse that became entangled at various moments with both the tendentious SlavophileWesternizer debates, and later with ideas of Eurasianism: Fabian 2019, 588-96. 
From the kurgans that graced the backdrops for the first production of Stravinsky's "Rite of Spring," to the vivid imagery of Alexander Blok's post-Decemberist Pan-Eurasian poem, "Skify," references to the ancient steppe suffused Russian art, literature, and selfperception. ${ }^{18}$

An influential early 20th-century scholarly approach to the question of Russia's steppe ancestry emerges in Rostovtzeff's 1922 Greeks and Iranians in South Russia. In the conclusion to the volume, Rostovtzeff writes, "The history of Russia as an economic and political organism is much more ancient than the earliest references to the Slavonic race . . . Russia as a country existed long before the 9th century, and formed part of the civilized world even in the classical period." 19 Rather than building an argument on the basis of a genetic connection between Scythians and later Slavs, Rostovtzeff instead makes an argument about a physical space. ${ }^{20}$ The North Pontic steppe supported a particular pattern of life, an "economic and political organism," that was identifiably Russian in antiquity. ${ }^{21}$

These varying approaches to the steppe have, for over two centuries, entwined the story of steppe peoples with a search for a Russian national past, at times dramatically politicizing research on mobile pastoralists writ large. ${ }^{22}$ Although this body of scholarship does not limit mobile pastoralists to the North Pontic and Volga-Don nor does it deal explicitly with the range of communities living in the North Caucasus, it does place a strong emphasis on the nomadic character of these spaces, and often on macro-scale questions of migration. In light of this research perspective, historical accounts and material culture related to Scythian/Sarmatian/Alan communities that has been found in the South Caucasus - distant from the steppe heartland and across the supposed barrier of the Greater Caucasus range- - has often been assumed to be intrusive or anomalous. ${ }^{23}$

Scholarship on the South Caucasus outside of the Russophone sphere, meanwhile, has until recently been rooted in the study of the (classical) textual corpus. Building on the image that emerges from that source tradition, researchers have paid considerable attention to questions about the location and control of passes through the mountains, connected with military campaigns. ${ }^{24}$ The locations of these passes have, however, been vexing since the time of Pliny, who noted widespread confusion. ${ }^{25}$ The mountains, furthermore, are more porous than the ancient sources would have us believe, while the evidence for large-scale investment in securing even the largest passes in the pre-

18 See e.g., Kunichika 2012, 235-42.

19 Rostovtzeff 1922, 211.

20 Although a genetic connection is posited: Rostovtzeff 1922, 219.

21 For perspectives on Rostovtzeff's thesis within the context of theories of Eurasianism, see Meyer 2009.

22 On the pressures over the course of the 20th century surrounding the migrations of Sarmatian tribes and other mobile pastoralists: Frachetti 2011, 197-200; Mordvinceva 2013b, 207-216.

23 There are of course exceptions, e.g., Gadžiev 1997 on the mosaic character of Dagestan; Abramova 1978 on decentralized steppe political landscapes.

24 E.g., Anderson 1928; Sanford 1937; Carrata Thomes 1958; Bosworth 1977; Syme 1981; Giardina 1996. These subjects have been of interest to Russophone scholars as well.

25 Pliny, $N H$ 6.40. His clarification, however, does little to elucidate the situation. 
Christian period is limited. ${ }^{26}$ Control of movement through the mountains was absolutely central to local power; but this control required cooperation.

I argue that the depictions of the Artašid and P'arnavazid dynastic marriages reflect the importance of interactions between social elites across the Greater Caucasus watershed range during the formational period of the pre-Christian South Caucasus, which gave them access to this form of cooperation. The marriages demonstrate that the border between the sedentary and mobile worlds - a border that has come to be conflated with the Caucasus Mountains themselves - was being crossed regularly. The cross-Caucasus relationships were significant enough that their memory was preserved in the much later textual tradition, although in a garbled form. This paper begins by contextualizing the two central North-South unions within a discussion of dynastic marriage in the South Caucasus, demonstrating the centrality of this political tool. Then, I survey the main lines of evidence for broader elite interaction between South and North Caucasian groups in the pre-Christian period, which includes both onomastic and paratextual materials, as well as some limited classical textual evidence. When these lines of evidence are considered in combination, a picture of intense cross-Caucasus interaction stretching back into the Late Hellenistic period emerges, making it impossible to ignore the northern neighbours in the story of the South Caucasus.

\section{The People of the North}

Before starting that story, however, several questions must be addressed: Who were these North Caucasian neighbours? To what communities or political entities did they belong? What interests did they have in the South Caucasus? The opacity of the world of the North Caucasus precludes complete answers, but it is possible to sketch the broad contours. Despite the coexistence of various communities in the North Caucasus with different lifeways and different patterns of mobility, this space has been considered, by and large, as the southern fringe of the steppe. Uncertainty about how to make sense of pastoralists and steppe spaces is not a new problem. As Pliny the Elder noted in his discussion of the steppe around the Caspian Sea, "in no other part [of the world] is there greater incontinency among the authors, I think that it is because of the immense number of peoples and their nomadism." ${ }^{27}$

The most common ethnonym used by both $\mathrm{MX}$ and the $\mathrm{KC}$ for the early phase of the northern neighbours is Alan (Arm. Alank'; Geo. Ovsis). MX uses this term explicitly in his description of Sat'enik. The story in the $\mathrm{KC}$ is more complicated. $\mathrm{P}^{\prime}$ arnavaz' bride is described only as being from Durżuket ${ }^{\prime} i$, and is not considered to be Alan - a point that is clear since the source distinguishes between the Durżuk kinsmen of Saurmag's mother and the Alan kinsmen of Saurmag's father. ${ }^{28}$ The ancient North Caucasus was clearly

26 Archaeological research at both of the major passes in recent years has demonstrated abundant investment in Late Antiquity, but little for earlier periods, although this picture may change with further research: Gadžiev 2008; Sauer et al. 2015; Lawrence - Wilkinson 2017.

27 Pliny, NH 6.18: nec in alia parte maior auctorum inconstantia...

$28 \mathrm{P}$ 'arnavaz had married his sister to the king of the Alans: $K C$, ed. S. Qauxč išvili 1955, 24, ll. 2-3; Thomson 1996, 33 . 
remembered by the medieval authors as a place of multiple overlapping communities, in a remembrance that matches with what we know about the region from other research. Nevertheless, the Alans are the most prominent of the North Caucasus groups in the local historiographical tradition, and also appear frequently in the classical sources. ${ }^{29}$

According to the standard schematization, the Alans are considered a late-stage Sarmatian community or federation, speaking an East Iranian language, to whom the modern Ossetians trace their decent. ${ }^{30}$ Moving backwards in time, and still following the traditional schema, the Sarmatians were an earlier group of East Iranian-speaking pastoralists who came to dominate the Western Steppe in the second half of the first millennium BCE while also maintaining ties further to the east. ${ }^{31}$ These Sarmatians displaced the earlier steppe power, the Scythians, also an Iranian-speaking group with their heartland in the North Pontic, thought to be present into Mesopotamia and Anatolia in the first half of the first millennium BCE alongside the Cimmerians. Beyond their linguistic and cultural connections, the other feature that united these various steppe populations was their reliance on pastoralism and mobile lifeways based on stockraising. ${ }^{32}$

Thus, the Alans of the South Caucasus' transmitted texts were the last in a continuum of Iranian-speaking peoples said to emerge from the Eurasian steppe belt during the Late Iron Age. As with the Alans, there is both textual and archaeological evidence for the presence of these earlier groups of steppe peoples in the South Caucasus, although the political context for that presence is hard to ascertain. ${ }^{33}$ And yet, basic facts about Alan society remain debated, with knowledge about the later Alans of the Great Migration period being both richer and better understood. When exactly did the earlier Alans emerge, and where and how did they live? How did they fit into the landscape of other (related?) pastoralist groups present in the North Caucasus? Did they have a singular 'ethnic' identity, or were they instead a federation of some sort? ${ }^{34}$ In principle, the mobility and lack of territorial centralization of the Alans and other steppe groups

29 Alemany 2000 on sources on the Alans in the various traditions.

30 Shnirelman 2006 with reservations about the Ossetian-Alan identity discourse.

31 Mordvinceva 2013b, 2013a, 2015 and Dan 2017 offer theoretical-historiographic perspectives on Sarmatian developmental narratives.

32 There is, however, a great degree of diversity within pastoralist practice, 'nomads' is an oversimplification For long durée perspectives on mobile pastoralist adaptation: Honeychurch 2014a; Hammer - Arbuckle 2017.

33 That is, were they present in the course of sporadic raiding activities, or were they participants in a deeper way in local life? There are allusions to these earlier northerners in local sources, discussed often as 'Khazars,' see Shapira 2007, 321-325. Historical and archaeological opinions about the presence of these groups in the South Caucasus center around how to understand the purported "Scythian Rule over Asia" (Hdt. 1.103-106, 130; 4.1-4, 12), see Vinogradov 1964; Aliev 1979; Esajan - Pogrebova 1985; Ivantchik 1999; Mehnert 2008.

34 For example, on the traditional quadripartite chronology for Sarmatian/Alan development, see Grakov 1947; Smirnov 1964; compared to other versions in Simonenko 2009, 11; Skripkin 1990. Other groups often mentioned in conjunction with the Alans, either as ancestors or as otherwise related, include the Massagetae (Cass. Dio 69.15.1) and Alanorsi (Ptol. Geog. 6.14.9). See Smirnov 1950, 106-111 on a standard archaeological paradigm to run alongside the texts. See also Jacenko 2003. For archaeological approaches to these questions, see Abramova 1993, 2005. 
resulted in a kaleidoscope of communities, such that the few collective ethnonyms preserved in the textual record capture only a small part of the story. ${ }^{35}$

My intent in discussing the North Caucasian resonances in the stories of Artašēs and

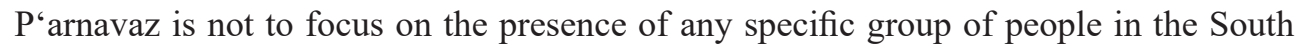
Caucasus. Rather, I call attention to evidence that suggests regular, and in some cases widespread, interactions across the Greater Caucasus watershed range over the course of several hundred years, which interwove the local communities and nascent political

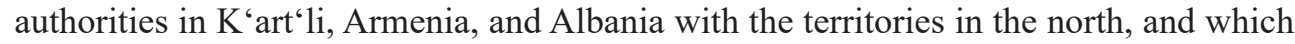
had clear consequences for the development of power in the south.

\section{North-South Caucasus Marriage Diplomacy}

The idea that dynastic marriages are an effective tool in pre-modern diplomacy that facilitated interstate interaction meets with little scepticism. ${ }^{36}$ Evidence for marriage as a form of diplomacy is abundant from diverse contexts in the ancient Near East and Mediterranean. Vivid examples of unions of this type are preserved in the Amarna Letters; ${ }^{37}$ poetic deployments of the trope colour Virgil's account of Rome's first hero, Aeneas; ${ }^{38}$ and they were used as a fundamental tool in Parthian domestic and foreign policy. ${ }^{39}$ These types of relationships were a durable way of building mutual interest and reciprocal responsibilities between parties that might otherwise engage in conflict.

Dynastic marriages between nomadic communities and sedentary neighbours are attested in many periods from both ends of the Eurasian steppe. Early in the Han Empire, heqin ("peace through kinship") agreements were a foundational component of HanXiongnu diplomacy. ${ }^{40}$ Although less formalized in character, there are examples of dynastic Greek-Scythian marriages from the Pontic basin as well. ${ }^{41}$ Later, the Mongols and Yuan Chinese intermarried extensively, as did the Muscovites and Tartars in the Early Modern period. ${ }^{42}$ Despite — or perhaps because of - the many differences between the social organization and governing logic of the so-called Steppe Empires and their neighbours, ${ }^{43}$ relationship-building through the extension of kinship networks appears to have been an effective strategy for developing political frameworks that spanned across diverse communities.

35 Amm. Marc. 31.17 describes this situation precisely.

36 Watkins 2017.

37 Cohen 1996.

38 Monti 1981, chap. 4.

39 Dąbrowa 2018.

40 Chin 2010, 311.

41 E.g., according to Herodotus (4.78-80), the Scythian king Ariapeithes took three wives, one a Greek from Istria, the second the daughter of a Thracian king, and the third a Scythian.

42 Martin 2008; Zhao 2008.

43 Khazanov's thesis of nomadic non-autarky $(1994,69-84)$ has been central to models of steppesedentary interaction and co-evolution, e.g., Barfield 2001; Di Cosmo 2011, 2015; Honeychurch 2013, 2014b; Turchin 2009, $196 f f$. 


\section{I.1. Early Dynastic Ties}

A dense network of dynastic relationships stretched across southwestern Asia during the Hellenistic, Parthian, and Roman periods. ${ }^{44}$ By tapping into this network, the South Caucasus gained political access to the wider Hellenistic world, where kinship networks shaped fortunes as local leaders negotiated for positions in the context of expanding Roman and Parthian spheres. The intent of the following section is to demonstrate the depth of those networks, and situate them in time. This exploration will make clear that marriage politics were a self-conscious strategy of political power, and lay the groundwork for seeing the North Caucasus as a participant in that system.

\section{I.1.1. Armenia}

Beyond Artašēs and Sat'enik — to which we'll return momentarily — we have scattered mentions of dynastic marriages from the Armenian historical tradition that may refer to the Hellenistic period, but are very difficult to date. Most interestingly, MX (2.11) notes that a certain King Artašēs gave one of his sisters to a King Mithridates described

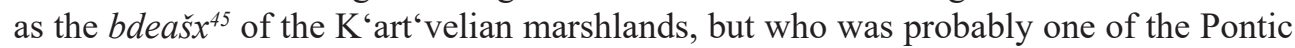
Mithridates. ${ }^{46}$ We are on firmer historical ground by the 1 st century BCE, when a variety of foreign sources report Armenian-Iranian dynastic intermarriage, through which the Artašēsid dynasty came to be closely entwined with various Parthian King of Kings. A clear instance of this is attested in one of the Avroman parchment documents found in 1909, which mentions in passing that one of the wives of a Parthian king, possibly Tigranes II (r. 95-55 BCE), was Aryzate, the daughter of a king of Armenia. ${ }^{47}$

She is thought to be one of the daughters of Kleopatra of Pontos and Tigranes, whose marriage had occurred in the context of the alliance between the Armenians and Mithridates. ${ }^{48}$ Another of their daughters is said to have married into the Atropatenian ruling family. ${ }^{49}$ A range of classical sources document a later Artašēsid-Parthian dynastic marriage between Tigranes the Younger and the daughter of Phraates III of Parthia (r. 69-57 $\mathrm{BCE}$ ), which occurred in the context of internecine fighting between Armenian factions. ${ }^{50}$ A later Armenian-Parthian union was between the sister of the Armenian king Artavasdes (r. 55-34 BCE) and Pacoros, the son of the Parthian king Orodes II (r. 57-37

44 For example, on the dynastic connections in Kappadokia or the Herodian Kingdom, see e.g., Sullivan $1978,1980$.

45 Often translated as 'viceroy,' or following Rapp, as 'toparch,' this was an office attested in both the Georgian and Armenian as well as in the Sasanian world. On the institution: Garsoïan 1989, 516-517; Hewsen 1988-1989, 1990-1991; Rapp 2014, 60-72; Sundermann 1989.

46 Garsoïan 1989, 516-517; Hewsen 1988-1989, 1990-1991; Rapp 2014, 62-71; Sundermann 1989 on the misunderstandings and conflations of the Mithridates in this passage of MX. See also Gazzano 2016; Mari 2016. The question of South Caucasus interaction with the Pontic Kingdom deserves more consideration.

47 Dąbrowa 2018, 77-78 on debates surrounding the dating of this parchment. Luther 2018 proposes a later dating of the parchment, which would re-date the marriage to the time of Tigranes the Great's son.

48 Just. 38.3.2, 5.

49 Cassius Dio 36.14.

50 Plut. Pomp. 33.6; Appian, Mithr. 104; Cass. Dio 36.51.1; 37.6.4. 
BCE). ${ }^{51}$ The wedding of these two was the staging ground for one of Plutarch's most striking scenes: the decapitated head of the defeated Roman M. Licinius Crassus used as a prop in production of Euripides' Bacchae. ${ }^{52}$

Artavasdes had earlier betrothed one of his daughters to Deiotarus I, sitting on the throne in Armenia Minor. ${ }^{53}$ There were also other Armenian-Anatolian dynastic unions, as between Archelaos I Sisines of Kappadokia (r. 36 BCE-15/16 CE) and an unnamed Armenian princess. ${ }^{54}$ Their daughter Glaphyra went on to marry into the Herodian dynasty, and passed along a claim to the Armenian throne to her son Tigranes V. ${ }^{55}$ In the tumult of Roman-Parthian struggle for supremacy in Armenia, claimants to the throne, including Tigranes $\mathrm{V}$ and his nephew Tigranes VI, invoked these dynastic ties - but others, like Zeno Artaxias (r. 13 BCE-34 CE) assumed the throne without such ties.

Although dynastic struggles continue throughout the 1 st and 2nd centuries CE, the frequency of dynastic marriage in the classical sources declines, although the Georgian tradition describes this as a time of ongoing Armenian- $\mathrm{K}^{6} \mathrm{art}^{6}$ velian unions. There is some mention of dynastic politics among the Armenian leading families (MX 63), although use of MX for this period is complicated by the telescoping of much of the relevant material. ${ }^{56}$ However, in MX 2.83, for example, we find a hint of later intermarriage between the Armenian dynastic family and northerners, in the story of the marriage of the late 3rd century king Trdat the Great to a certain Ašxēn. Although her heritage was not named in MX, she was understood by later authors in the Armenian tradition to have been Alan. ${ }^{57}$

\section{I.1.2. $K^{\prime}$ 'art'li}

The machinations of the K'art'velian monarchy, who played a more minor role in strife between Hellenistic kingdoms and between the Roman and Parthian authorities, are less well-documented in the classical sources. But, a tight web of dynastic marriage between Armenian and $\mathrm{K}^{6}$ art'velian lines is recorded in the Georgian tradition, although as Traiana has recently said, "local historiography presents these marriages with blurred tones, usually difficult to put in a clear historical context." 58

Allusions to these networks appear from the earliest days of the $\mathrm{P}^{\text {‘ }}$ arnavazid dynasty in the $\mathrm{KC}$ : $\mathrm{P}^{\prime}$ arnavaz himself was described as being of mixed heritage, descended on his paternal side form the eponymous east Georgian leader $\mathrm{K}^{\text {' }} \operatorname{art}^{`}$ los, while his mother was said to be a Persian. ${ }^{59} \mathrm{He}$ gave his sister in marriage to the king of the Alans. ${ }^{60}$

51 Plut. Crass. 33.1.

52 Plut. Crass. 32-33.

53 Cic. Ad Att. 5.21.2.

54 Cass. Dio 49.39.2

55 Augustus, Res Gestae 27.2; Sullivan 1990, 300.

56 See note 45.

57 On this connection, see Thomson 1978, 233 note 2. On possible etymologies of her name, see Alemany 2000, 300.

58 Traina 2019, 123.

59 Rapp 2014, 204-213 for a broader consideration of the account of P'arnavaz in the $K$ 'artlis Cxovreba. The image of P'arnavaz elsewhere in the Georgian tradition is attenuated, see Rapp 2003, 274-280.

$60 K C$, ed. S. Qauxč išvili 1955, 24, ll. 2-3; Thomson 1996, 33. 
His son, Saurmag, whose parentage was already discussed, married the daughter of an Iranian governor (erast'avi) in Partaw (mod. Brdo), which Toumanoff understood as an anachronistic reference to an Albanian-Arsakid princess. ${ }^{61}$ Their adopted son, Mirvan I, arranged a marriage between his daughter and the son of the Armenian Artašēsid king, Artšak. ${ }^{62}$ Artašak's grandson, Bartom, married an Armenian Artašēsid princess, and seeking to secure his family's claim in the absence of a male heir, married his daughter back into the P'arnavazid line. ${ }^{63}$ Although his daughter's husband was killed before assuming the throne, their son Aderki was said to claim kingship for himself on the basis of his $\mathrm{P}^{\prime}$ arnavazid lineage, ruling in the early 1 st century CE.

By the 1st century CE, growing foreign interaction between $\mathrm{K}^{\text {'art' }} \mathrm{li}$ and the Romans raised their profile in classical sources, leading to a number of discussion of local kings. ${ }^{64}$ There are significant problems, however, in reconciling the Georgian sources for this period with texts from the classical world. According to the Georgian sources, this was a period of diarchy that continued into the 2nd century CE, with one king supposedly ruling at $\mathrm{Mc}^{6} \mathrm{xet}^{6} \mathrm{a}$ and another at Armazi. ${ }^{65}$ The institution of diarchy is not mentioned in the classical texts, although they do reflect intense internecine drama which is reminiscent of that described in local historiography. ${ }^{66}$

Two recently discovered inscriptions from a bath complex at the site of Bagnet' $i$,

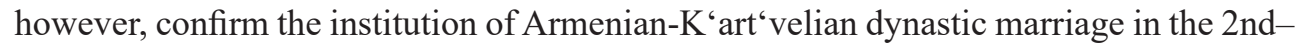
3rd century CE ${ }^{67}$ The dedicatory inscriptions refer to the marriage of Drakontis, the daughter of an Armenian king Ouologaisos (Vologases = Vałarš?) to an Iberian king Amazaspos. ${ }^{68}$ Debates over dating have suggested a range of possibilities, based largely on attempts to match the events to known dynasts bearing the name Vałarš and Amazaspos. The $\mathrm{KC}$ also notes continued intermarriage between the ruling $\mathrm{K}^{\text {'}}$ art ${ }^{6}$ velian Arsakid dynasty (189-284 CE) and elite families from both the Roman East and Iran. At the start of the dynasty, we find the marriage of Rev Mart'ali (r. 189-216 CE) to a woman from the Eastern Roman world, the daughter of a logothete. ${ }^{69}$ Further dynastic marriages are

$61 K C$, ed. S. Qauxč išvili 1955, 27, ll. 15-16; Thomson 1996, 38; Toumanoff 1969, 9, note 45.

62 The king in question is thought to be Artavasdes I. This dynastic union became important in future years, when the other K'art'velian families felt that Mirvan's successor, P'arnajom, strayed too far from local custom in adopting Iranian practices, and appealed to the Armenians to install Artšak, with his $\mathrm{P}^{\prime}$ arnavazid wife, as king (KC, ed. S. Qauxč išvili 1955, 29, ll. 5-15; Thomson 1996, 42).

$63 K C$, ed. S. Qauxč išvili 1955, 32.

64 E.g., Plut. Pomp. 34; Tac. Ann. 6.32-36; 12.44-45; Cass. Dio 36.53-37.5; 58.26.1-4; 69.15.1-2; HA Had. 17.10-12; HA Ant. Pius 9.6.

65 The historicity of the five pairs of kings has been debated, see Rapp 2014, 223, note 188 for bibliography.

${ }_{66}$ This drama also includes the marriage of close familial members within $\mathrm{K}$ 'art'li's ruling family.

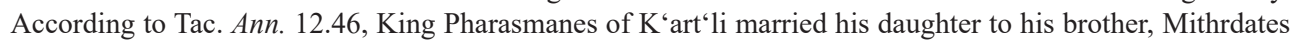
who was installed on the throne of Armenia. Furthermore, the son of Pharasmanes and the daughter of Mithridates were also wed.

67 T. Qauxč išvili 1999-2000, II: nos. 198-199; Braund 2002; Traina 2004, 2019. On the third, very fragmentary, inscription that was part of the bathhouse dedication, see T. Qauxč išvili 1999-2000, II: no. 200, and Preud'homme 2019a, who suggests a mid-2nd century date for the dedication.

68 Braund 2002, 30-31 on debates on the date of Vałarš.

$69 K C$, ed. S. Qauxč išvili 1955, 59, l. 2; Thomson 1996, 68. She is referred to as being from Saberżnet ' $i$, literally "Greece," although the term was used freely to refer to both the Roman and the Byzantine Empires, see Rapp 2014, 258, note 374; Toumanoff 1954, 161, note 222. 
reported between members of the Chosroid dynasty (284-580 CE) and women from the imperial family of the Eastern Roman Empire. ${ }^{70}$

Tracing the full dynamics of intermarriage in Armenian and Georgian contexts across this broad time is beyond the scope of this paper. However, the examples mentioned here demonstrate both Armenia's and K'art'li's multi-focal external relationships. Some of these relationships can be attributed to the earliest phases of Armenian and Georgian state consolidation, with the start of the Artašēsid and $\mathrm{P}^{\text {' }}$ arnavazid dynasties. However, they only begin to show up in foreign sources where the chronology is more certain at the beginning of the 1st century BCE, as the South Caucasus's strategic value increased, bringing intensified historical reporting about the region.

\section{Other Evidence of Elite Interaction}

That leaves us with a central question: how do we make sense of the two North-South marriages in the local historical traditions, and what period of history might they reflect? We could interpret them both as a retrojection of later realities, and thus reject their relevance for the either the Hellenistic or the Roman/Parthian periods (or both); or we could see them as fragile evidence of the oft-forgotten northern people, remembered hostilely by their neighbours, who left almost no historical testimony of their own.

Despite the lack of explicit mentions of other North-South unions in the textual sources, we find further clues of steppe presence in elite life in the South Caucasus in both the Hellenistic and Roman/Parthian periods, to which we now turn. This proxy evidence will never fully answer the question posed above, but it does lend weight to the latter proposition, namely that the local historical tradition is, in broad strokes, correct in stressing cross-Caucasus relationships in the development of the South Caucasus, beginning at the latest in the Late Hellenistic period.

In the following discussion, I focus on clues in several textual or para-textual sources. I avoid one significant category of archaeological data that has frequently been mustered in discussions of steppe presence in the South Caucasus - mortuary evidence. The mortuary material is too large and complex to be treated in brief. The identification of individual ethno-cultural identity on the basis of mortuary practice is furthermore not straightforward, particularly in light of our current understandings of both North and South Caucasus evidence. ${ }^{71}$

70 Two instances are noted, one between Arč ‘il and a relative of Emperor Jovian $(K C$, ed. S. Qauxč 'išvili 1955, 140); and a second between Vaxtang and a relative of Emperor Zeno (KC, ed. S. Qauxč 'išvili 1955, 198).

${ }^{71}$ See recently Sagona - Sagona - Michalewicz 2017 on evidence from one well documented cemetery, although pertaining to a later period than discussed here. 


\section{I.1.3. Onomastic Evidence}

Onomastic clues about the involvement of North Caucasian families in the elite politics of the South Caucasus are fairly widespread. The most obvious line of evidence comes from the Georgian transmitted texts, with names like Saurmag and K'art'am identified as having possible East Iranian (i.e., Sarmato-Alan) associations. ${ }^{72}$ For example, in an alternative version of the early history of $\mathrm{K}^{\prime}$ 'art'li preserved in the Mok'c 'evay k'art 'lisay,

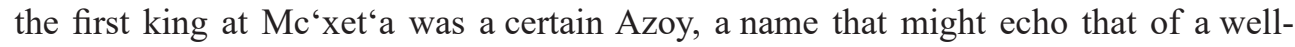
known Indo-Scythian king Azēs and be based on an East Iranian root. ${ }^{73}$

Excavated inscriptions add dimension to this picture, although the chronological resolution of this material is coarse, and none of it predates the late 1 st century CE. Chief here are two inscribed stele from Georgia, both of which were found reused in later contexts at the Armazis-q evi necropolis in the course of the Mc'xet'a excavations. ${ }^{74}$ The earlier of the two is a monolingual Armazian inscription, which has been dated by some to as early as the 70's CE; the later is an Armazian-Greek bilingual, which dates probably to the mid-2nd century $\mathrm{CE} .{ }^{75}$ The monolingual is a victory stele representing the

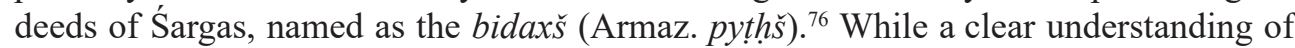
the various battles and alliances described on the stele is hindered by the wide range of toponyms that cannot be securely identified, it likely records that Śargas won a victory against the Armenians. He accomplished this in conjunction with a range of local allies. The later bilingual inscription records the death of Serapit, the daughter of a bidax š Zewah the Younger (Gr. Zēouach).

The inscriptions yield several names that have been identified as East Iranian. The name Zewah, for example, that appears on both inscriptions as well as on at least three other smaller objects from graves in the region is also attested on an inscription at Tanais. ${ }^{77}$ Another name from the monolingual with a plausible East Iranian etymology, Asparug (Gr. Aspauroukis), appears in a Greek form on a signet ring found during excavations at Mc'xeta, with Asparug named as the pitiaxēs. ${ }^{78}$ Even more explicit is an inscribed intaglio that dates likely to the 3rd century CE from Žinvali, bearing a Greek inscription

72 See the discussion in Rapp 2014, 226-227.

73 Rapp 2014, 227.

74 Apakidze et al. 1958, 69-73, Plate LIX. On these: Cereteli 1941, 1948; Nyberg 1946.

75 On the monolingual: Cereteli 1962; Altheim - Stiehl 1963, I: 243-261; Preud'homme 2019b. On the better-known bilingual (SEG XVI 781), see Metzger 1956; Carrata Thomes 1958; Bosworth 1977, 230-231; Ceret'eli 1992; Braund 1994, 212-214; Rapp 2014, 215.

76 See above note 44.

77 From Mtskheta, it appears clearly on gemstone set into a belt (Apakidze et al. 1958, pl. XLV 3), on a gold ring (Apakidze et al. 1958, 79, fig. 135.16), and possibly in an abbreviated form on a second ring (Apakidze et al. 1958, 48-49, fig. 19). The name, in Armazian, was also inscribed on a spoon found in later excavations at Bagneti (Apakidze 1973). For the name at Tanais, see Latyschev 1885-1901, no. 2.447, l. 17. On this name as an example of Scythian language, see also Abaev 1949, I: 190. For discussions of the name, see Chaumont 1975, 107; Wheeler 1977, 85; Braund 1994, 215.

78 Apakidze et al. 1958, 29, fig. 4. See discussion of this name in Abaev 1949, I: 157-158; Duičev 1953; Schmitt 1985; Rapp 2014, 65, note 162; Schottky 2016, 215-216. Following Schmitt and Schottky, this individual should not be connected with the later $\mathrm{K}^{\text {‘art }}$ 'velian king Asp'agur, although their names share a similar root. 
reading BAKOYR ALANA, which has been read as "Bakour the Alan."79 The name Bakour is otherwise known from the Georgian tradition, where two kings called Bakour and Bak'ar ruled between the early third and early 4th centuries respectively. A certain Bakkourious is also noted in foreign ecclesiastical histories as the king of his people. ${ }^{80}$

The onomastic evidence is certainly not concrete proof of North Caucasian affiliation — names can mark a range of other identity-formulations, like political ties — ${ }^{81}$ and its timeframe is very broad. Nevertheless, the volume of such names and their close connections to ruling families both in the 1st-2nd centuries CE and later, and the presence of some with explicit connections to the North Caucasus, are noteworthy.

\section{I.1.4. Tamgas}

The occasional presence of tamgas - symbols general associated with steppe communities or clans - in the South Caucasus offers further support for the presence of steppic people among the local elite. Tamgas and tamga-like signs are frequently found in Sarmatian contexts, and are thought to have served a range of functions including the marking of presence and of property ownership..$^{82}$ Despite their steppic associations, finds of tamgas in settlements and other sedentary spaces near steppe regions are not uncommon, where they are often associated with categories of material culture connected with authority and administrative power. ${ }^{83}$

Symbols that seem to be tamgas appear above the top line of Greek text on the Armazian monolingual inscription. ${ }^{84}$ These symbols have, however, been read in different ways, with early interpretation suggesting their connection to an early Georgian alphabet. ${ }^{85}$ The identification of the marks as tamgas is supported by the presence of tamgas below the text on a lesser known inscription found in western Azerbaijan, bearing a Greek funerary epitaph. ${ }^{86}$ This stele had been reused in a later grave, just as the Armazis$\mathrm{q}^{\mathrm{e}}$ evi example. In this second case, there is no doubt about the nature of the symbols; they find precise parallels in the North Caucasus. ${ }^{87}$

Tamgas are also attested on a range of small finds from across the northern South Caucasus, including on ceramics from the eastern Caucasus, ${ }^{88}$ and accompanying an inscrip-

79 Ramišvili - Džorbenadze 1976. See discussion in: Braund 1994, 247; Perevalov 2003; Balahvancev - Nikolaišvili 2010.

80 Ps.-Gelasios of Kyzikos 1.10.21.

81 It is in this way that Roman names among Caucasian elite are discussed, e.g., Braund 1993; Linderski 2007, 267, but also Linderski 2007, 273-276.

82 For surveys of tamgas, see: Solomonik 1959; Dračuk 1975; Jacenko 2001; Kuznecov 2007. For recent overviews, see: Kozlovskaja - Ilyashenko 2018; Muratov 2017, 187-190; Voronjatov 2009.

83 Kozlovskaja - Ilyashenko 2018, 172-173.

84 For assessments that see the marks as tamgas, see Altheim - Stiehl 1963, 250; Wheeler 1977, 82-84; Preud'homme 2019b, 1.

85 Apakidze et al. 1958, 72. This argument echoes the recurrent association between tamgas and various other alphabets and proto-scripts, see discussion in Manassero 2013.

86 Trever 1959, 340-341, Plate 36.

87 Jacenko 2001, 76.

88 Jacenko 2001, 76, note 19. 
tion in Greek on a silver vessels from Mc'xeta. ${ }^{89}$ Here, two tamga-like symbols appear at the centre of a silver plate bearing an inscription marking its transfer from a king Flavius Dades to a pitiaxēs Bersouma. ${ }^{90}$ The fact that many of these tamgas occur alongside Greek or Armazian inscriptions mirrors the association of the tamgas and texts in the North Pontic, ${ }^{91}$ and leads one to wonder whether the tamgas were used to increase legibility of the other writing systems for a particular audience.

\section{I.1.5. Classical Ethnographies}

Finally, ethnographic and historical accounts from the classical tradition also offer limited evidence for both social and military frameworks drawing the North and South Caucasus together. Strabo provides the most detailed and comprehensive classical treatment of the South Caucasus. ${ }^{92}$ His account suggests that, on a political level, there was a clear boundary between the nomads of the north and the sedentary polities of the Armenians, $\mathrm{K}^{\text {' }}$ art'velians, whom he calles Iberians, and Albanians to the south:

As for the Armenians, and the peoples who are situated above Colchis, both Albanians and Iberians, they require the presence only of men to lead them, and they are excellent subjects, but because the Romans are engrossed by other affairs, they make attempts at revolution... whereas the nomads, on account of their lack of intercourse with the others, are of no use for anything and only require watching. ${ }^{93}$

And yet, the stark dichotomy between the nomadic and sedentary populations dissolves when Strabo considers ethnic or cultural dimensions of society. Speaking of the 70 different peoples who lived in the mountains beyond Black Sea port of Dioscurias, Strabo says, "the greater part of them are Sarmatians (Sarmatae), but they are all Caucasian (Caucasii)."94 More explicitly, he describes the highland inhabitants of K'art'li and Albania as kinsmen of their Sarmatian neighbours to the north.$^{95}$ According to Strabo, these genetic ties justify the military collaboration of the nomadic northerners and their South Caucasian brethren against external threats. ${ }^{96}$ Beyond his own family ties to Pontos, he is thought to have drawn on other witnesses, including Pompey's companion Theophanes of Mytilene, which would place this information in a Late Hellenistic context. ${ }^{97}$

89 Apakidze et al. 1958, 60-63, Plate LIV. The identity of the king named in this inscription has been the subject of considerable debate, with some seeing him as a North Caucasian leader, see: Melikišvili 1959, 56-58; Braund 1993; Balahvancev 2005; Linderski 2007. For a recent argument for a late (4th century) date, see Coert - Schmitt 2019.

90 Note also the scratched Greek text below Bersouma, MAKEDONI, on which Linderski 2007, 270.

91 Kozlovskaja - Ilyashenko 2018, 177-180 for an overview of tamgas and inscriptions, and bibliography.

92 Strabo 11.1.3-4, 13-14. See also discussions of Strabo's depiction of Armenia (Traina 2017), K`art'li (Boltunova 1947), and Albania (Aliev 1975).

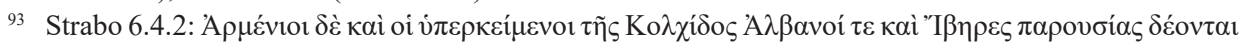

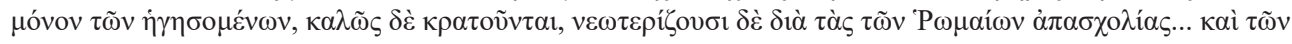

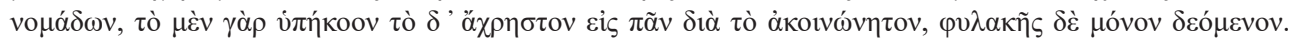
Trans. Jones 1917-1932.

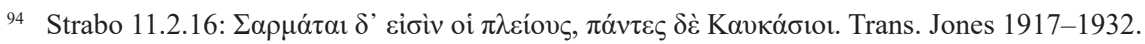

95 Strabo 11.3.3; 11.4.5.

96 Strabo 11.4.5.

97 Meißner 2000, 183-189 on the role of Theophanes's testimony. Quellenforschung with the goal of understanding how recent Strabo's sources for book 11 were has been a common topic for ancient historians, 
Beyond Strabo, the classical corpus offers descriptions of Alan/Sarmatian military actions unfolding in the South Caucasus. Three episodes explicitly involving North Caucasian forces are attested during the first two centuries $\mathrm{CE}$, one in $35 \mathrm{CE}$, a second in ca. $72 \mathrm{CE}$, and a third in $135 \mathrm{CE} .^{98}$ There is what appears to be a reference to these conflicts in the Georgian tradition as well, although it is hard to place in time. ${ }^{99}$ Without going into detail about the nuances of these fights, it is enough to point out that the episodes present a combination of internal unrest or disagreement between factions, but also collaboration between diverse groups. ${ }^{100}$ These three fairly brief accounts of the Alan raids in the 1 st and 2 nd centuries offer instances of military collaboration between North and South Caucasian groups, and also military aggression between and within the communities. The dynamic nature of regional alliances offers a clue about why diplomatic strategies like dynastic marriage were critical.

\section{Artašēs, P'arnavaz, and their Wives}

By way of conclusion, we return to the to the stories of Artašēs and P'arnavaz, fleshing out the two accounts and elaborating some noteworthy details, tackling the challenging question of chronology, and finally contextualizing them within the discussion above.

In the case of $\mathrm{P}^{\prime}$ arnavaz and his son, Saurmag, it is important to note simply that the story is very much in keeping with the picture of multi-focal complexity laid out in both the survey of dynastic marriages and the classical accounts. Saurmag had familial connections not only to his mother's North Caucasian siblings, but also to the Alans, who were cousins on his father's side through marriage. Furthermore, beyond the Durżuks and the Alans, the KC's account of Saurmag makes an (anachronistic) reference to a third steppe group, the Khazars, who were said to be hostile towards the Durżuks. ${ }^{101}$ By assembling a coalition, Saurmag could control movement between the North and South Caucasus and thus defeat his challengers. He earned the throne, and granted the Durżuks rights to expand into the South Caucasus. ${ }^{102}$ The picture that emerges is of unstable alliances, and victories won through kinship-driven collaboration, the foundation of which was laid by P'arnavaz’ shrewd marriage alliances.

\footnotetext{
e.g., Kauchtschischwili 1978.

9835 CE: Tacit. Ann. 6.33-35; Josephus, Ant. Iud. 18.96-97; ca. 72 CE: Josephus, Bell. Iud. 7.244-251; 135 CE : Cass. Dio 69.15.1-3.

$99 K C$, ed. S. Qauxč 'išvili 1955, 33-54, also Toumanoff 1969, 2-3, 12-13. Josephus is also considered a source for MX 2.50: Thomson 1978, 57.

100 Thus, in $35 \mathrm{CE}$, some 'Sarmatians' choose to align with the $\mathrm{K}^{\text {'art }}$ 'velian king against the Parthians, while others do not join: Tac. Ann. 6.33. The geography surrounding the second raid in ca. 72 is a disputed matter (e.g., Bosworth 1977, 223, note 24. For a survey of opinions, see Bais 2001, 88), but the account is clear that the Alans had to negotiate with local (sedentary?) kings to secure passage through their lands. Finally, in $135 \mathrm{CE}$, the $\mathrm{K}^{\text {'art }}$ 'velians and Albanians come into direct conflict, with the Alans acting at first at the behest of the K'art'velian king to attack the Albanians, and then enticed by Parthian bribes, continuing on to attack the Romans: Cass. Dio 69.15.1-3.

$101 K C$, ed. S. Qauxč išvili 1955, 27 l. 6.

$102 K C$, ed. S. Qauxč išvili 1955, 27 ll. 8-11.
} 
The story of Artašēs and Sat'enik lacks this level of intrigue. However, the episode provides a richer picture of social life between communities. In addition to the general narrative, MX provides the story-tellers' version of Artašēes and Sat'enik's marriage. According to MX, when the bards tell the story, they first describe how Artašēs met Sat'enik; how he captured her with a lasso made of a red leather strap; and how they were wed in a rich ceremony accompanied by showers of gold and pearls. ${ }^{103}$ In explaining the unexpected appearance of the lasso in the bardic account, MX provides a clarification: "The truth of this is as follows. Because red leather (mort" karmir) is greatly prized among the Alans, [Artašēs] gave much lac (layk'a) and gold as payment." ${ }^{104}$ The mention a bride-price paid in gold and layk' $a$ (a hapax) is intriguing. ${ }^{105}$ One cannot help but think here of red lacquer objects of Han provenience known to be prized among the Alans and other steppe peoples, which are to this day misidentified as "red leather" by researchers. ${ }^{106}$ Whether or not this association withstands scrutiny, the cultural dimension of marriage interaction provides a particularly rich glimpse into local relationships. Finally, it should be mentioned that this story appears in multiple Armenian sources, although other versions are less elaborated and mostly clearly derivative. ${ }^{107}$ There are also resonances between Sat'enik in her Armenian form, and a Caucasian princess, Satana, in the various North Caucasus versions of the Nart epics, which demonstrates the long and deep circulation of the narrative building blocks of this story across the Caucasus among multiple communities. ${ }^{108}$ These echoes themselves show that cross-Caucasus cultural connections have historically been the rule rather than the exception.

That brings us to the final point, which is about chronology. It is not my intent to suggest that these intriguing details can be located chronologically with any degree of precision, nor to demonstrate that they contain precise, perfect memories of local realities at a specific moment in the Caucasus' pre-Christian history. Quite the opposite: we must be clear that these stories will only ever offer a fuzzy picture of antiquity.

The traditional period of rule of Saurmag, reckoned according to the Georgian sources, is from 234-159 BCE, ${ }^{109}$ with Artašēs' regnal dates also in the first half of the 2nd century BCE. So, taken on face value, we would place both stories in the 3rd-2nd century BCE. MX's account of Artašēs is, however, chronologically muddled. He is depicted as the power that overthrew the Eruandid (Orontid) dynasty — an event that

103 Movsēs Xorenac‘i 2.50.

104 “Or ew čšmartowt'eamb owni ayspēs. K'anzi patoweal ē ā̄ Alans mort' karmir layk'a šat ew oski bazowm taweal i varjans ar̄now ...” Trans. Thomson 1978, 193.

105 Thomson 1978, 193, note 7; Alemany 2000, 290 with bibliography.

106 On lacquer objects in the western steppe, and the issue of their misidentification, see Prüch 2019, especially 11-12, note 4. These were familiar high-status exports from the Han Empire, and are known from Sarmato-Alan archaeological contexts.

107 Fritz - Gippert 2003 for a survey. Note the interesting case of the transformation of the story in Movsēs Dasxuranc'i's Patmut 'iwn Atuanic' ašxarhi (1.8) where the princess becomes Albanian rather than Alan, see trans., Dowsett 1961, 7.

108 Dumézil 1929; Dowsett 1986; Fritz - Gippert 2003; Russell 2018. For a sample of the range of Satana, see Colarusso 2002, especially Sagas 46-49. Once again, there is a question about the direction of influence between these traditions, see Russell 2018.

109 Toumanoff 1963, 9-10. But, see reservations about these dates discussed in note 2 . 
must have happened in the late 3rd century $\mathrm{BCE},{ }^{110}$ but also the successor to Sanatruk, who ruled in the late 1 st century CE. ${ }^{11}$ Armenian historians are largely in agreement that this is the result of compounding confusions in the source tradition, and they associate Artašēs with the early 2nd century BCE historically attested Artašēs I. ${ }^{112}$

But that leaves us with a question: does Sat'enik reflect an early 2nd century BCE element of the story, or is she part of a later layer? In support of a later date, she is explicitly called an Alan maiden (óriordn Alanc), with the appearance of Alans in the North Caucasus placed around the 1st century BCE, if not later. ${ }^{113}$ And indeed, southward raids of Alans of the type possibly described in the story are attested by classical sources only in the mid- and late 1 st century $\mathrm{CE}$ and later. Carrata-Thomes, therefore, simply accepts a 1st-century reign for Artašēs and his marriage to Sat'enik. ${ }^{114}$ Alemany, wishing to retain a later date for the Alan bride while also following the early date for Artašēs, argues that the account preserves "the memory of historical facts from different periods" overlaid on local folk traditions. ${ }^{115}$ Fritz and Gippert, more specifically, suggest that the marriage occurred between the 1st and 3rd century CE, between an Alan princess and a king bearing the eponymous dynastic name/title Artašès; thus the story came to be associated with the earlier Artašēs. ${ }^{116}$

These attempts to situate the story within a historical framework, however, overlook two issues. First, anachronistic ethnic nomenclature and ethnic metonymy are widespread in etic accounts of steppe communities. ${ }^{117}$ Both the Armenian and Georgian textual traditions, after all, use the even more anachronistic term 'Khazar' to refer to early steppe communities. ${ }^{118}$ The fact that Sat'enik is called an Alan does not itself disqualify an earlier date. Second, all three solutions are predicated on the belief that the classical sources provide an accurate reflection of the episodes of aggression between the North and South Caucasians, namely that such aggressions only began in the 1 st century $\mathrm{CE}$, and were relatively confined to that period. They, implicitly or explicitly, ${ }^{119}$ rule out earlier episodes of North-South Caucasus conflict. However, the trope of fighting between the people of the North and South is embedded in the earliest mythological accounts of regional history, with archaeological and foreign historical sources demonstrate that such conflict was present periodically in the Iron Age. ${ }^{120}$ The

110 Movsēs Xorenac‘i 2.37-46.

111 Movsēs Xorenac'i 2.37.

112 See note 1 on Toumanoff's assessment.

113 Although classical sources begin to reference Alans in the 1st century CE, the date of the Alan material cultural complex is said by most to be considerably later, in the second (Malašev 2010) or even 3rd century CE (Abramova 1997).

114 Carrata Thomes 1958, 21. See also Alemany 2000, 289 for these various approaches.

115 Alemany 2000, 289.

116 Fritz - Gippert 2003, 408-409.

117 To pick one relevant example of confusing ethnic terms, compare Josephus, Ant. Iud. 18.97.4, which

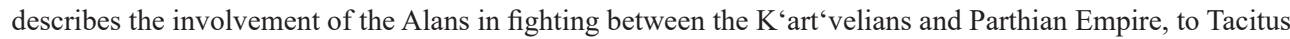
Ann. 6.33, 35, which credits the Sarmatians with the same activities.

$118 K C$, ed. S. Qauxč išvili 1955, 13, l. 8 on Iron Age Khazars; Movsēs Xorenac 'i 2.65 on the Khazars during the 2nd-century CE.

119 E.g. Alemany 2000, 289: “. . . nor is there any sense of speaking of Alan incursions ca. 160 BCE.”

120 E.g., Scythian raids in earlier periods. 
fact that we know of specific battles only in the 1st century CE may well be a mirage resulting from the more abundant foreign textual record for these periods, and the more direct impact that Alan raids had on Roman interests. ${ }^{121}$

A different solution for understanding the chronological problem is offered by Gabrieljan, who suggests that the term "Alan' should be taken to mean "northerners" more broadly, ${ }^{122}$ which seems to be the most plausible, if not entirely satisfying, understanding. We can't be certain that Sat'enik is, in fact, Hellenistic in date; but there is no convincing reason to say that she couldn't be. Saurmag's case is more opaque, because of a lack of external confirmation of this early phase of $K^{\text {' }}$ art'velian rule, but the same general logic holds.

Based on these texts alone, then, the chronology is uncertain. But, when we consider the two reports side-by-side, and in light of the other evidence for elite interaction discussed above, we find ourselves of firmer ground for imagining that the accounts reflect at least some elements of the Late Hellenistic Caucasus. The robust network of Late Hellenistic dynastic marriages suggest that such unions were a familiar strategy for local dynasts certainly by the early 1st century BCE, if not earlier. The foreign ethnographic work of Strabo, which largely reflects 1st-century BCE sources, is unambiguous about the close connections between the sedentary and mobile pastoralist communities in this period. The onomastic and para-textual evidence comes from 1st-century CE and later archaeological contexts, but it suggests that East Iranian names were widely dispersed among local elites by this point.

The stories of the cross-Caucasus marriages of Artašēs and $\mathrm{P}^{\prime}$ arnavaz are, therefore, in keeping with our understanding of local conditions in the Late Hellenistic period, although there is no way to exclude a later date. Wherever we place them in history, however, it is clear that these interactions between north and south were deep and ongoing. They were also foundational to development on both sides of the watershed range. We can no longer relegate the northerners to the role of occasional nomadic interlopers, but must rather integrate them as a critical part of the regional system.

BIBLIOGRAPHY

Abaev, V. I. (1949), Osetinskij jazik i folklor [Ossetian Language and Folklore], vol. 1, Moskva. Abramova, M. P. (1978), K voprosu ob Alanskoj kul'ture Severnogo Kavkaza [On the Question of the Alan Culture of the North Caucasus], Sovetskaja arheologija 1: 72-82.

Abramova, M. P. (1993), Central'noe Predkavkaz'e v Sarmatskoe Vremja (III v. do n.è-IV v. n. è) [The Central Predcaucasus in the Sarmatian Period (3rd c. BCE-4th c. CE)], Moskva.

Abramova, M. P. (1997), Rannie Alany Severnogo Kavkaza III-Vvv. n.è [The Early Alans of the North Caucasus, 3rd-5th c. CE], Moskva.

121 As exemplified by the Arrian's Ektaxis kata Alanōn, Bosworth 1977 on the Roman concern about the Alans.

122 Gabrieljan 1989, 70. 
Abramova, M. P. (2005), Idiosyncrasies of the Formation Process of the North Caucasian Alan Culture: Based on Archaeological Data, Ancient West \& East 4: 122-139.

Alemany, A. (2000), Sources on the Alans: A Critical Compilation, Leiden-Boston.

Aliev, I. G. (1975), K interpretacii paragrafov 1,3,4 i 5 IV glavy XI knigi 'Geografii’ Strabona [On the Interpretation of Paragraphs 1, 2, 3, 4 and 5 of Section 4 of the Eleventh Book of Strabo's "Geography"], Vestnik drevnej istorii 133: 150-165.

Aliev, I. G. (1979), O skifah i Skifskom cartsve v Azerbajdžane [On the Scythians and the Scythian Kingdom in Azerbaijan], in: Peredneaziatskij sbornik. Vyp. III. Istorija i filologija stran drevnevo vostoka [Near Asia Miscellanea, part 3: History and Philology of the Countries of the Ancient East], Moskva: 5-14.

Altheim, F., Stiehl, R. (1963), Die Aramäische Sprache unter den Achaimeniden, vol. 1, Frankfurt a. Main.

Anderson, A. R. (1928), Alexander at the Caspian Gates, Transactions and Proceedings of the American Philological Association 59: 130-63.

Apakidze, A. M. (1973), Baginet'is k'ldik'aris sarkopagi [A Sarcophagus of Baginet‘i, Kldikari], Dzeglis megobali 33: 59-65.

Apakidze, A. M. et al. (1958), Mcheta. Itogi arheologičeskih issledovanij. Arheologičeskie pamjatniki Armazis-hevi po raskopam 1937-1946 gg. [Mtskheta. Results of Archaeological Research: Archaeological Monuments of Armazis-Khevi Excavated in 1937-1946], Tbilisi.

Bais, M. (2001), Albania caucasica: Ethnos, storia, territorio attraverso le fonti greche, latine e armene, Milano.

Balahvancev, A., Nikolaišvili, V. (2010), 'Alan Bakur' iz drevnej Iberii ['Alan Bakour' from Ancient Iberia], Rossijskaja arheologija 9(4): 130-135.

Balahvancev, A. S. (2005), Car' Flavij Dad [King Flavius Dades], Numizmatika i èpigrafika 17: 44-55.

Barfield, T. J. (2001), The Shadow Empires: Imperial State Formation along the Chinese-Nomad Frontier, in: S. E. Alcock et al. (eds.), Empires: Perspectives from Archaeology and History, Cambridge: $10-41$.

Boltunova, A. I. (1947), Opisanie Iberii v 'Geografii' Strabona [The Description of Iberia in Strabo's Geography], Vestnik drevenj istorii 4: 142-160.

Bosworth, A. B. (1977), Arrian and the Alani, HSCP 81: 217-255.

Braund, D. (1993), King Flavius Dades, ZPE 96: 46-50.

Braund, D. (1994), Georgia in Antiquity: A History of Colchis and Transcaucasian Iberia, $550 B C-A D 562$, Oxford.

Braund, D. (2002), Anagranes the TPOФEY Centuries AD, in: Autour de la mer Noire. Hommage de Otar Lordkipanidzé, (Collection de l'Institut des Sciences et Techniques de l'Antiquité), Besançon: 23-34.

Carrata Thomes, F. (1958), Gli Alani nella politica orientale di Antonino Pio, Torino.

Cereteli, G. V. (1941), Armazskaja Bilingva [The Bilingual of Armazi], Tbilisi [non vidi].

Cereteli, G. V. (1948), Èpigrafičeskie nahodki v Mcxeta - drevnej stolice Gruzii [Epigraphic Finds from Mtskheta - The Ancient Capital of Georgia], Vestnik drevnej istorii 1948: 49-57.

Cereteli, G. V. (1962), Armazskaya nadpis‘ èpohi Mitridata Iberijskogo [Armazian Inscription from the Time of Mithridates of Iberia], in: Trudy XXV meždunarodnogo kongressa vostokovedov [Proceedings of the XXV International Congress of Orientalists], vol. 1, Moskva: 374-378.

Ceret'eli, K. (1992), Šenišvnebi armazis bilingvis arameul tekstze [Remarks on the Armazian Text of the Armazi Bilingual], Tbilisi.

Chaumont, M.-L. (1975), États vassaux dans l'empire des premiers Sassanides, Acta Iranica 4: $89-156$.

Chin, T. T. (2010), Defamiliarizing the Foreigner: Sima Qian's Ethnography and Han-Xiongnu Marriage Diplomacy, Harvard Journal of Asiatic Studies 70: 311-354. 
Chrzanowski, T. (1988), Sarmatyzm - mity dawne i współczesne [Sarmatism: Ancient and Contemporary Myths], in: T. Chrzanowski (ed.), Wędrówki po Sarmacji europejskiej: eseje o sztuce i kulturze staropolskiej [Wanderings in European Sarmatia: Essays on Old Polish Art and Culture], Kraków: 7-29.

Coert, J., Schmitt, T. (2019), Wer war Fl. Dades? Überlegungen zum Verständnis einer Inschrift aus dem kaukasischen Iberien, in: V. Cojocaru et al. (eds.), Advances in Ancient Black Sea Studies: Historiography, Archaeology and Religion, Cluj-Napoca: 347-390.

Cohen, R. (1996), All in the Family: Ancient Near Eastern Diplomacy, International Negotiation 1.1: 11-28.

Colarusso, J. (2002), Nart Sagas from the Caucasus: Myths and Legends from the Circassians, Abazas, Abkhaz, and Ubykhs, Princeton.

Dąbrowa, E. (2018), Arsacid Dynastic Marriages, Electrum 25: 73-83.

Dan, A. (2017), The Sarmatians: Some Thoughts on the Historiographic Invention of a West Iranian Migration, in: F. Wiedemann, K. P. Hofmann, H.-J. Gehrke (eds.), Vom Wandern der Völker: Migrationserzählungen in den Altertumswissenschaften, Berlin: 97-134.

Di Cosmo, N. (2011), Concepts of the Polity: Ethnogenesis, Coevolution, and Political Morphology of the Earliest Steppe Empire: The Xiongnu Question Revisited., in: U. Brosseder, B. K. Miller (eds.), Xiongnu Archaeology: Multidisciplinary Perspectives of the First Steppe Empire in Inner Asia, Bonn: 35-48.

Di Cosmo, N. (2015), China-Steppe Relations in Historical Perspective, in: J. Bemmann, M. Schmauder (eds.), Complexity of Interaction along the Eurasian Steppe Zone in the First Millennium CE, Bonn: 49-72.

Djurslev, C. T. (2018), Revisiting Alexander's Gates against 'Gog and Magog': Observations on the Testimonies before the Alexander Romance Tradition, in: R. Stoneman, K. Nawotka, A. Wojciechowska (eds.), The Alexander Romance: History and Literature, Eelde: 201-214.

Dowsett, C. F. J. (1961), The History of the Caucasian Albanians by Movsēs Dasxuranc'i, London.

Dowsett, C. F. J. (1986), Little Satana's Wedding Breakfast, in: D. Kouymjian (ed.), Armenian Studies: In Memoriam Haig Berberian, Lisboa: 243-263.

Dračuk, V. S. (1975), Sistemy znakov Severnogo Pričernomor'ja: tamgoobraznnye znaki sebernopontijskoj periferii anticnogo mira pervyh vekov našej èry [Systems of Signs of the North Black Sea: Tamga-like Symbols of the North Pontic Periphery of the Ancient World in the First Centuries of Our Era], Kiev.

Duičev, I. (1953), Imja Asparuh v novootkrytyh nadpisjah Gruzii [The Name Asparukh on a Newly Discovered Inscription of Georgia], Archiv Orientálni 21: 353-356.

Dumézil, G. (1929), Le Dit de la princesse Satinik, Revue des Études Arméniennes 9: 41-53.

Esajan, S. A., Pogrebova M. N. (1985), Skifskie pamjatniki Zakavkaz'ja [Scythian Monuments of Transcaucasia], Moskva.

Fabian, L. (2019), Russian Perspectives on Eurasian Pasts, in: S. von Reden (ed.), Handbook of Ancient Afro-Eurasian Economies, vol. 1: Contexts, Berlin: 581-618.

Frachetti, M. D. (2011), Migration Concepts in Central Eurasian Archaeology, Annual Review of Anthropology 40: 195-212.

Fritz, S., Gippert, J. (2003), Armeno-Ossetica: Zum historischen Hintergrund des Nartenepos, in: N. N. Kazanskij (ed.), Hŗdá Mánasā. Sbornik statej k 70-letiju so dnja roždenija Professora L. G. Gercenberg [Hṛdá Mánasā: Collection of Articles for the Seventieth Birthday of Professor L. G. Gertsenberg], Sankt-Peterburg: 385-420.

Gabrieljan, R. A. (1989), Armjano-alanskie otnošenija: I-Xvv. [Armenian-Alan Relations, 1st10th Century], Erevan.

Gadžiev, M. S. (1997), Meždu Evropoj i Aziej: iz istorii torgovyh svjazej Dagestana v albanosarmatskij period [Between Europe and Asia: From the History of Trade Relations of Dagestan in the Albano-Sarmatian Period], Mahačkala. 
Gadžiev, M. S. (2008), On the Construction Date of the Derbend Fortification Complex, Iran and the Caucasus 12(1): 1-15.

Gagoshidze, I., Löhr, H., Ludwig, N. (2008), Kartli in Hellenistic and Roman Times: General Aspects, in: A. E. Furtwängler (ed.), Iberia and Rome: The Excavations of the Palace at Dedoplis Gora and the Roman Influence in the Caucasian Kingdom of Iberia, Langenweissbach.

Garsoïan, N. G. (1989), The Epic Histories: Attributed to P'awstos Buzand (Buzandaran Patmut'iwnk'), Cambridge, MA.

Gazzano, F. (2016), Croesus' Story in the History of Armenia of Movsēs Xorenac 'i, in: F. Gazzano, L. Pagani, G. Traina (eds.), Greek Texts and Armenian Traditions: An Interdisciplinary Approach, Berlin: 83-114.

Giardina, A. (1996), Roma e il Caucaso, in: Il Caucaso: Cerniera fra culture dal Mediterraneo alla Persia (secoli $I V-X I)$, Spoleto: 85-142.

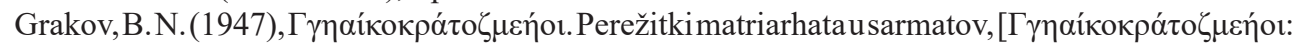
Traces of Matriarchy among the Sarmatians], Vestnik drevnej istorii 3: 100-121.

Gregoratti, L. (2013), The Caucasus: A Communication Space between Nomads and Sedentaries (1st BC-2nd AD), in: S. Magnani (ed.), Le aree montane come frontier. Spazi d'interazione e connettività, Roma: 525-540.

Hammer, E. L., Arbuckle B. S. (2017), 10,000 Years of Pastoralism in Anatolia: A Review of Evidence for Variability in Pastoral Lifeways, Nomadic Peoples 21: 214-267.

Hewsen, R. H. (1988-1989), Introduction to Armenian Historical Geography IV: The Vitaxates of Arsacid Armenia. A Reexamination of the Territorial Aspects of the Institution (Part One), Revue des Études Arméniennes n.s. 21: 271-319.

Hewsen, R. H. (1990-1991), Introduction to Armenian Historical Geography IV: The Vitaxates of Arsacid Armenia: A Reexamination of the Territorial Aspects of the Institution (Part Two), Revue des Études Arméniennes n.s. 22: 147-183.

Honeychurch, W. (2013), The Nomad as State Builder: Historical Theory and Material Evidence from Mongolia, Journal of World Prehistory 26: 283-321.

Honeychurch, W. (2014a), Alternative Complexities: The Archaeology of Pastoral Nomadic States, Journal of Archaeological Research 22: 277-326.

Honeychurch, W. (2014b), Inner Asia and the Spatial Politics of Empire: Archaeology, Mobility, and Culture Contact, New York.

Ivantchik, A. I. (1999), The Scythian 'Rule over Asia': The Classical Tradition and the Historical Reality, in: G. R. Tsetskhladze (ed.), Ancient Greeks West and East, Leiden: 497-520.

Jacenko, S. A. (2001), Znaki-tamgi iranojazyčnyh narodov drevnosti i rannego srednevekov'ja [Symbol-Tamagas of the Iranian-Speaking Peoples of Antiquity and the Early Middle Ages], Moskva.

Jacenko [Yatsenko] S. A. (2003), Peculiarities of Social Development of the Sarmato-Alans and Their Image in the Evidence of Other Cultures, in: N. N. Kradin, D. M. Bondarenko, T. J. Barfield (eds.), Nomadic Pathways in Social Evolution, Moskva: 88-99.

Jones, H.L. (1917-1932), Strabo's Geography, Cambridge.

Karamzin, H. M. (1818), Istorija gosudarstva rossijkogo [The History of the Russian State], vol. 1, Sankt-Peterburg.

Kauchtschischwili, T. (1978), Strabon und das alte Georgien, Philologus 122: 68-87.

Khazanov, A. M. (1994), Nomads and the Outside World, 2nd ed., Madison, WI.

Kozlovskaja, V., Ilyashenko, S. I. (2018), Tamgas and Tamga-like Signs from Tanais, in: Zeichentragende Artefakte im sakralen Raum. Zwischen Präsenz und Unsichtbarkeit, Berlin: 167-198.

Kunichika, M. (2012), 'The Scythians Were Here . . .': On Nomadic Archaeology, Modernist Form, and Early Soviet Modernity, Ab Imperio 2: 229-257.

Kuznecov, V. D. (2007), Tamga Savromata II iz Fanagorii [A Tamga of Sauromates II from Phanagoria], Drevnosti Vostoka 11: 225-234. 
Latyschev, V. V. (ed.) (1885-1901), Inscriptiones antiquae orae septentrionalis Ponti Euxini Graecae et Latinae, 4 vols., Sankt-Petersburg.

Lawrence, D., Wilkinson, T. J. (2017), The Northern and Western Borderlands of the Sasanian Empire: Contextualizing the Roman/Byzantine and Sasanian Frontier, in: E. W. Sauer (ed.), Sasanian Persia: Between Rome and the Steppes of Eurasia, Edinburgh.

Linderski, J. (2007), How Did King Flavius Dades and Pitiaxes Publicius Agrippa Acquire Their Roman Names?, in: J. Linderski, Roman Questions II, Stuttgart: 262-276.

Luther, A. (2018), Zu den Dokumenten aus Avroman, Gymnasium 125: 155-177.

Malašev, V. I. (2010), Central'nye rajony Severnogo Kavkaza v pozdnesarmatskoj vremja [The Central Region of the North Caucasus in the Late Sarmatian Period], in: Stanovlenie $i$ razvitie pozdnesarmatskoj kul'tury (po arheologičeskim $i$ estestbennonaučnym dannym), [Formation and Development of the post-Sarmatic Culture (according to the Archaeological and Naturalistic Evidence)], Volgograd: 117-142.

Manassero, N. (2013), Tamgas and Literacy among the Ancient Iranians, Re:marks. The Journal of Signum 1: 43-61.

Mari, F. (2016), Cyrus the Great in Movsēs Xorenac'i, Patmut'iwn Hayoc': Telescoping the King, in: F. Gazzano, L. Pagani, G. Traina (eds.), Greek Texts and Armenian Traditions: An Interdisciplinary Approach, Berlin: 115-142.

Martin, R. E. (2008), Gifts for the Bride: Dowries, Diplomacy, and Marriage Politics in Muscovy, Journal of Medieval and Early Modern Studies 38: 119-145.

Mehnert, G. (2008), Skythika in Transkaukasien: Reiternomadische Sachkultur im archäologischen Fundkontext, Wiesbaden.

Meißner, B. (2000), A Belated Nation: Sources on Ancient Iberia and Iberian Kingship, Archäologische Mitteilungen aus Iran und Turan 32: 177-206.

Melikišvili, G. A. (1959), K istorii drevnej Gruzii [For the History of Ancient Georgia], Tbilisi.

Metzger, B. M. (1956), A Greek and Aramaic Inscription Discovered at Armazi in Georgia, Journal of Near Eastern Studies 15: 18-26.

Meyer, C. (2009), Rostovtzeff and the Classical Origins of Eurasianism, Anabases 9: 185-197.

Monti, R. C. (1981), The Dido Episode and the Aeneid: Roman Social and Political Values in the Epic, Leiden.

Mordvinceva, V. (2013a), Istoričeskie sarmaty u sarmatskaja arheologičeskaja kul’tura v Severnom Pričernomor'e [The History of the Sarmatians and Sarmatian Archaeological Culture in the North Black Sea], in: N. Hapunov, Krym v sarmatskuju èpochu (II v. do n. ̀-IV v. n.è.) [Crimea in the Sarmatian Period (II BCE-IV CE), vol. 1, Simferopol': 14-43.

Mordvinceva [Mordvintseva], V. (2013b), The Sarmatians: The Creation of Archaeological Evidence, Oxford Journal of Archaeology 32: 203-219.

Mordvinceva, V. (2015), Sarmaty, Sarmatija i Severnoe Pričernomor'e [Sarmatians, Sarmatia and the North Black Sea], Vestnik drevnej istorii 1: 109-135.

Muratov, M. (2017), The Language(s) of Images in the Arts of the Bosporan Kingdom, in: V. Kozlovskaya (ed.), The Northern Black Sea in Antiquity: Networks, Connectivity, and Cultural Interactions, Cambridge: 169-191.

Nyberg, H. S. (1946), Quelques inscriptions antiques découvertes récemment en Géorgie, Eranos Rudbergianus 44: 228-243.

Perevalov, S. M. (2003), Bakur-Alan iz drevnej Iberii [Bakur-Alan from Ancient Iberia], Nartamongae 2: 47-56.

Preud'homme, N. J. (2019a), Aurelie and Divus Verus-New Reading of a Greek Inscription from Armazi, Iberia-Colchis 15: 201-213.

Preud'homme, N. J. (2019b), La stèle des victoires su pițahš Śargas et la réaffirmation de la domination royale en Ibérie du Caucase, Camenulae 22: 1-20. 
Prüch, M. (2019), From East to West: The Journey of Han-Dynasty Lacquer Boxes to the Crimean Peninsula, in: A. Kieser, P. Frick (eds.), Production, Distribution and Appreciation: New Aspects of East Asian Lacquer Ware, Leiden: 10-29.

Qauxč išvili, S. (ed.) (1955), Kartlis cxovreba [K'art'lis c'xovreba], Tbilisi.

Qauxč išvili, T. (1999-2000), Sak'artvelos berdznuli carcerebis korpusi [Corpus of the Greek Inscriptions of Georgia], 3 vols., Tbilisi.

Ramišvili, R. M., Džorbenadze, V. A. (1976), Arheologičeskie issledovanija v zone stroitel'stva Žinval'skogo Gidrotehničeskogo kompleksa [Archaeological Research in the Construction Zone of the Zhinvali Hydraulic Complex], in: Arheologičeskie issledovanija na novostrojkah Gruzinskoj SSR [Archaeological Research for the New Constructions in the Socialist Republic of Georgia], Tbilisi: 30-44.

Rapp, S. H. (2003), Studies in Medieval Georgian Historiography: Early Texts and Eurasian Contexts, Leuven.

Rapp, S. H. (2009), The Iranian Heritage of Georgia: Breathing New Life into the Pre-Bagratid Historiographical Tradition, Iranica Antiqua 44: 645-692.

Rapp, S. H. (2014), The Sasanian World through Georgian Eyes: Caucasia and the Iranian Commonwealth in Late Antique Georgian Literature, Farnham.

Roaf, M. (2012), Could Rusa Son of Erimena Have Been King of Urartu during Sargon's Eighth Campaign?, in: S. Kroll et al. (eds.), Biainili-Urartu: The Proceedings of the Symposium Held in Munich 12-14 October 2007 / Tagungsbericht Des Münchner Symposiums 12.-14. Oktober 2007, Leuven: 187-216.

Rostovtzeff, M. I. (1922), Iranians and Greeks in South Russia, Oxford.

Russell, J. R. (2018), Argwan: The Indo-European Memory of the Caucasus, Nartamongce 13: 151-187.

Sagona, A., Sagona, C., Michalewicz, A. (2017), Alans in the Southern Caucasus?, in: F. J. Vervaet, H. J. Kim, S. F. Adalı (eds.), Eurasian Empires in Antiquity and the Early Middle Ages: Contact and Exchange between the Graeco-Roman World, Inner Asia and China, Cambridge: 205-250.

Sanford, E. M. (1937), Nero and the East, HSCP 48: 75-103.

Sauer, E.W. et al. (2015), Northern Outpost of the Caliphate: Maintaining Military Forces in a Hostile Environment (the Dariali Gorge in the Central Caucasus in Georgia), Antiquity 89: 885-904.

Schmitt, R. (1985), Asparuch und Konsorten im Lichte der iranischen Onomastik, Linguistique Balkanique 28: 13-38.

Schottky, M. (2012), Vorarbeiten zu einer Königsliste Kaukasisch-Iberiens. 1. Anfänge der Pharnabaziden, Anabasis 3: 239-250.

Schottky, M. (2016), Vorarbeiten zu einer Königsliste Kaukasisch-Iberiens. 5. Im Schatten Schapurs II., Anabasis 7: 204-221.

Shapira, D. (2007), Armenian and Georgian Sources on the Khazars: A Re-Evaluation, in: P. Golden, H. Ben-Shammai, A. Roná-Tas (eds.), The World of the Khazars, Leiden: 307-352.

Shaw, B. D. (1982), Eaters of Flesh, Drinkers of Milk: The Ancient Mediterranean Ideology of the Pastoral Nomad, Ancient Society 13-14: 5-31.

Shnirelman, V. (2006), The Politics of a Name: Between Consolidation and Separation in the Northern Caucasus, Acta Slavica Iaponica 23: 37-73.

Simonenko, A. V. (2009), Sarmatskie vsadniki Severnogo Pričernomor'ja [Sarmatian Riders of North Pontic Region], Sankt-Peterburg.

Skripkin, A. S. (1990), Aziatskaja Sarmatija. Problemy hronologii i eë istoričeskij aspect, [Asiatic Sarmatia: Problems of Chronology and Its Historical Aspect], Saratov.

Smirnov, K. F. (1950), Sarmatskie plemena Severnogo Prikaspija [The Sarmatian Tribes of the North Pre-Caspian], Kratkie soobščenija instituta istorii material'noj kul'tury 23: 97-114. 
Smirnov, K. F. (1964), Savromaty. Rannaja istorija i kul'tyra sarmatov [Savromatians: Early History and Culture of the Sarmatians], Moskva.

Solomonik, E. I. (1959), Sarmatskie znaki Severnogo Pričernomor'ja [Sarmatian Symbols of the Northern Black Sea], Kiev.

Sulimirski, T. (1964), Sarmatians in the Polish Past, The Polish Review 9: 13-66.

Sullivan, R. D. (1978), The Dynasty of Judaea in the First Century, ANRW 2.8: 296-354.

Sullivan, R. D. (1980), The Dynasty of Cappadocia, ANRW 2.7.2: 1125-1168.

Sullivan, R. D. (1990), Near Eastern Royalty and Rome, 100-30 BC, Toronto.

Sundermann, W. (1989), Bidaxš, EI 4: 242-244.

Syme, R. (1981), Hadrian and the Vassal Princes, Athenaeum 59: 273-283.

Thomson, R. W. (1978), Moses Khorenats' $i$ : History of the Armenians, Cambridge, MA.

Thomson, R. W. (1996), Rewriting Caucasian History: The Medieval Armenian Adaptation of the Georgian Chronicles. The Original Georgian Chronicles and the Armenian Adaptation, Oxford.

Toumanoff, C. (1954), Christian Caucasia between Byzantium and Iran: New Light from Old Sources, Traditio 10: 109-189.

Toumanoff, C. (1963), Studies in Christian Caucasian History, Washington, DC.

Toumanoff, C. (1969), Chronology of the Early Kings of Iberia, Traditio 25: 1-33.

Traina, G. (2004), Un dayeak armeno nell'Iberia precristiana, in: V. Calzolari, A. Sirinian, B. L. Zekiyan (eds.), Bnagirk' Yišatakac'. Documenta memoriae dall'Italia e dall'Armenia: Studi in onore di Gabriella Ulahogian, Bologna: 255-262.

Traina, G. (2017), Strabo and the History of Armenia, in: D. Dueck (ed.), The Routledge Companion to Strabo, London-New York: 93-101.

Traina, G. (2019), Dynastic Connections in Armenia and Iberia: Further Reflections on the Greek Inscriptions from Bagineti (SEG 52, No. 1509-1510), in: U. Hartmann, T. Stickler, F. Schleicher (eds.), Iberien zwischen Rom und Iran: Beiträge zur Geschichte und Kultur Transkaukasiens in der Antike, Stuttgart: 123-128.

Trever, K. V. (1959), Očerki po istorii i kul'ture Kavkazkoj Albanii IV v. do n.è.-VII v. n.è., [Studies on the History and Culture of Caucasian Albania: 4th Century BCE-7th Century CE], Moskva-Leningrad.

Turchin, P. (2009), A Theory for Formation of Large Empires, Journal of Global History 4(2): 191-217.

Van Bladel, K. (2007), The Alexander Legend in the Qur'an 18: 83-102, in: The Qur'an in Its Historical Context, London-New York: 191-219.

Vinogradov, V. B. (1964), O skifskih pohodah čerez Kavkaz, [On the Skythian Campaigns Throught the Caucasus], Trudy Čečeno-Inguškogo naučno-issledovatel'skogo Instituta 9: $21-48$.

Voronjatov, S. V. (2009), O funkcii sarmatskih tamg na sosudah, [On the Function of Sarmatian Tamagas on Vessels], in: Gunny, Goty $i$ Sarmaty meždu Volgoy i Dunaem [Huns, Goths, and Sarmatians between the Volga and the Danube], Sankt-Petersburg: 80-98.

Watkins, J. (2017), After Lavinia: A Literary History of Premodern Marriage Diplomacy, Ithaca, NY.

Wheeler, E. L. (1977), Flavius Arrianus: A Political and Military Biography, Ph.D. thesis, Duke University.

Zhao, G. Q. (2008), Marriage as Political Strategy and Cultural Expression: Mongolian Royal Marriages from World Empire to Yuan Dynasty, New York. 